many mistakes and particularly regret the blunder we made over the burial. My initial wish for a private funeral seemed a foolishly extravagant and self indulgent way of commemorating Alasdair so we opted for a free hospital burial, little realising that this meant consigning him to an anonymous, multiple grave. We chose not to attend the interment knowing that it would be too agonising, and when I later visited the cemetery I was unable to find any trace of his grave, merely being told by the attendant that it must be somewhere in the common ground. While in no way wishing to imply that we were coerced into this arrangement, I think that greater emphasis should be laid on the importance of making a rational decision in one's own time and that parents should be aware that although they can ask which cemetery their child is to be buried in, the grave itself may be unidentifiable.

\section{Registration procedure}

The experience of registering a stillbirth was also unexpectedly gruelling, the registrar's main preoccupation being whether we could prove that we were married. I was shocked to emerge from the office a few minutes later with nothing but a small receipt giving the hospital permission to proceed with the burial. I had misguidedly thought that we would be given the chance to name our baby and would receive a certificate to keep. I understand that the registration procedure in England and Wales has been modified since 1 April 1983 to take these factors into consideration and that the Scottish system is also under reviewtoo late for us, but I am sure that it will be of great benefit of other parents.
We both want to be positive about our experiences and would like to help others in a similar plight. The current research interest in the psychological aftermath of perinatal morbidity is encouraging but makes it all the more distressing to come up against outmoded hospital customs. Local policy made it almost inevitable that I would be returned from the delivery suite to a ward full of babies, but we both feel strongly that it should have been possible to find me a bed elsewhere in the hospital, perhaps in the nearby gynaecological ward. As doctors we ought to be able to tackle the system from the inside but have so far found ourselves to be as impotent as our lay companions.

We are naturally very nervous about future pregnancies and, working as I do in a department of child psychiatry, I wonder about the emotional development of later children of bereaved parents. Tragedy has taught us many valuable lessons, not least the recognition of each other's strengths and weaknesses. It will always be sad to remember Alasdair's birthday so we have decided instead to celebrate the date of his conception and to rejoice in his brief but enlightening existence.

\section{References}

${ }^{1}$ Forrest GC, Claridge RS, Baum JD. Practical management of perinatal death. $B r$ Med f 1981;282:31-2.

2 Standish E. The loss of a baby. Lancet $1982 ; \mathrm{i}: 611-2$

3 Health Education Council, National Association for Mental Health, and National Stillbirth Study Group. The loss of your baby. London: Health Education Council, 1979.

(Accepted 1 August 1983)

\title{
Clinical curio: Tribolium Macleay (Coleoptera: Tenebrionidae) infestation in children
}

During November 1980 one of us (BBB) took part in the pathological investigation of several children in Lancaster after a minute black insect had been observed on the scalps of two young girls. The first girl, aged 4 years, had a scab on the scalp which was lifted by the mother, who observed the insect underneath the scab. Consequently, seven associated children were examined, and a further insect was noted in a second girl, aged 6 years. The two girls were playmates and were the only children of the group thus affected, although several (not the girl with the scab) had pediculus eggs (nits).

One of the insects was sent to YZE, who identified it as a species of Tribolium Macleay (Coleoptera: Tenebrionidae) and it was specifically identified as $T$ destructor Uyttenboogaart by DJ de $\mathrm{CH}$. This species is a pest of stored products in the British Isles, although it is not as important a pest as the two other British species of Tribolium: T castaneum (Herbst) and T confusum Jacquelin du Val. It is, however, the species most commonly found in human habitations. ${ }^{1}$

We could find no reference to the occurrence of Tribolium or any other Tenebrionid in man in the medical or entomological publications. Laurent, however, records the effects of the secretion of another Tenebrionid, Blaps nitens Cast, during routine handling in the laboratory ${ }^{2}$; the beetles were reported to eject their secretion on to the author when handled, causing a burning sensation on the nose and lips. Another species of Blaps Fabricius, B judaeorum Miller, ejects a fluid that causes blisters on the skin. Although the vesicant properties of blister beetles of the family Meloidae have long been appreciated, ${ }^{34}$ the effects of the toxic secretions of the thoracic and abdominal glands of Tenebrionidae do not seem to be well documented in this regard. In his review of the medical importance of Coleoptera, Theodorides mentions Tenebrionidae only as intermediate hosts of helminths. ${ }^{5}$

The chemical composition of the odorous secretion of Tribolium species has been studied in some detail, ${ }^{6-10}$ and in all three British species it has been found to be mainly composed of quinones, whereas the secretion of Meloid beetles is cantharidin $\left(\mathrm{C}_{10} \mathrm{H}_{12} \mathrm{O}_{4}\right){ }^{5}$ Quinones are known to be carcinogenic, and a possible correlation between human malignancy and flour that has been contaminated by quinone secreting species of Tribolium has been suggested. ${ }^{11}$ The secretion is highly toxic to the beetles themselves ${ }^{8}$ and is said to have bactericidal properties. ${ }^{9}$ The function of these secretions is presumably defensive.

To see if any harmful effects were produced by the beetle on the skin a single living specimen of $T$ castaneum was placed (ventral side down) on YZE's left forearm and kept in position with sticky tape, the right arm acting as a control. After about an hour a mild irritating sensation was felt, which continued, but did not appreciably increase, during the next four hours, after which the bettle was removed and the arm examined. A slight depression was noted and the skin was raw. The injury healed within a day or two and no scar was left. This sort of injury is in sharp contrast to the fluid filled bullae caused by the canthraidin secreted by Meloids; in cases where severe vesiculation has occurred a noticeable scar is usually left.

Inquiries regarding the source of infection in the Lancaster children showed no association with stored products. The only positive finding was that all four parents concerned worked in the National Health Service. Any of them could therefore have acted as a vector with regard to one or both of the children, although if this were the case the infestation may have been more widespread than the two observed cases would suggest. We would like to thank Dr Lewis Davies of the Department of Zoology, University of Durham, for reading and commenting on the manuscript.-B B BEESON, consultant pathologist, Lancaster; D J DE COURCY HENSHAW, Waltham Abbey; Y Z ERZINÇLIOGLU, zoologist, Durham.

Dr Beeson died last year before this curio was submitted.

Brendell MJD. Tenebrionidae. Handbooks for the identification of British insects. Vol 5(10). London: Royal Entomological Society, 1975:1-22

aurent P. Auto-observation: effects de la sécrétion toxique du ténébrionide Blaps nitens Cast. Bulletin de la Société Zoologique de France 1939;64:20-3.

Lehmann CF, Pipkin JL, Ressmann AC. Blister beetle dermatosis. AMA Archives of Dermatology $1955 ; 71: 36-8$

$1946 ; 131: 594-5$. 1946 ;131:594-5.

The parasitological, medical and veterinary importance of coleoptera. Acta Trop (Basel) 1950:7:48-60.

Alexander P, Barton DHR. The excretion of ethylquinone by the flour beetle. Biochem f $1943 ; 37: 463-5$

Hackman RH, Pryor MGM, Todd AR. The occurrence of phenolic substances in arthropods. Biochem $\mathcal{F}$ 1948;43:474-7.

Loconti JD, Roth LM. Composition of the odorous secretion of Tribolium castaneum. Annals of the Entomological Society of America 1953;46:281-9.

Roth LM, Eisner T. Chemical defenses of arthropods. American Review of Ento mology $1962 ; 7: 107-36$.

Roth LM, Stay B. The occurrence of para-quinones in some arthropods, with emphasis on the quinone-secreting tracheal glands of Diploptera punctate of Insect Physiology 1958;1:305-18.

Ladisch RK. Quinones as food contaminants and carcinogens. Report of the Pioseries No 4 ). 